\title{
Social Media Content and Service Delivery Empowerment in Hospitality Businesses in Nigeria
}

\author{
Murtala Mohammed Alamai ${ }^{1 *}$, Godwin Matthew Sule ${ }^{2}$ and Aisha \\ Ahmad Aliyu ${ }^{3}$ \\ ${ }^{1}$ Leisure and Tourism Management Department, The Federal Polytechnic Bauchi, Nigeria \\ ${ }^{2}$ Mass communication Department, The Federal Polytechnic Bauchi, Nigeria \\ ${ }^{3}$ General Studies Department, The Federal Polytechnic Bauchi, Nigeria
}

\begin{abstract}
The research examines the current state of social media content and service delivery empowerment in hospitality and tourism businesses in Nigeria and it focuses on the relevance of social media as a panacea to tourism sector. The study builds from previous studies, especially those in the areas that are related to the study. The objectives of the study were to examine if tourists find related information through a social media platform used by the tourism and hospitality business in Nigeria. It also examines if Social media empowers the customers in the choice of services offered by hospitality and tourism businesses in Nigeria and to identify if user-generated content on social media influences the quality of service offered by hospitality and tourism businesses in Nigeria. The methodology employed in this study was quantitative analysis. A Purposive or non-probability sampling technique in selecting the respondents (hospitality and tourism business in Bauchi) from the population of the study was adopted. The result obtained uncovered that online reviews is the most used social media medium which is common among all the respondents and it also revealed that there is a high relation between social media platform and the quality of services offered which indicated an influence of social media and the quality of services offered.
\end{abstract}

Keywords: Social Media, Empowerment, Tourism, Hospitality, Service Delivery

\section{Introduction}

There is no doubt that over the years, social media have in many ways changed the way we communicate, interact, share and conduct our relationships with people around our environment especially, with friends, family, colleagues, politicians, news media, celebrities and organization alike (Reitz, 2012). The explosion of social media into the world have paved ways for effective communication and creating a mutual understanding among members of the society.

The dramatic transformation of the media landscape, inevitably connected to an array of social, economic, political and cultural factors, confronts us as a decisive yet still on-going development of the historical present. The emergent of internet on a mass scale in the Mid-1990s, modern electronic media and their affordances, as well the creative practices that emerge in the social media, are in constant transformation. In recent years, internet and its ancillary technologies, such as mobile phones and the platforms for social media have further extended this development. The use of Facebook, twitter, and YouTube have now become than important institutions of the Public sphere. Dahlgren (2013) described the concept of Web 2.0 as a pathfinder and convenient maker of a "technological transition" of social media signaling the increasing participatory character of the new media platforms.

Although, the real revolution of the social media and mass communication through the new media was actualized at the commencement of the third Millennium when Web 1.0 was moved to a new phase of its development, namely Web 2.0. This step meant, according to Tanase and Nicolta, (2014), the liberation from the-tyranny of technology. Furthermore, Web 2.0 was named the Internet of the users, developing a new model 
of mass communication, characterized by high degree of interaction between the broadcaster(s) and the online publics (2014)

The term Web 2.0 has become quite popular among social media publics. Many will definitely appreciate Tim O'Reilly who described it as a new type of collaborative Web (Allen, 2009), a platform harnessing collective intelligence (O’Reilly, 2005). Web 2.0 was later described by (Hoegg, Martignoni, Meckel, and StanoevskaSlabeva (2006) as the philosophy of mutually maximizing collective intelligence and added value for each participant by formalized and dynamic information sharing and creation. The definition given by (Anderson, 2007 ) involves the concept of a group of technologies that have become profoundly related to the term and have contributed to the creation of a more socially connected Web, where anyone can participate by adding and editing content. The short answer, for many people, is to make a reference to a group of technologies which have become deeply associated with the term: blogs, wikis, podcasts, RSS feeds, which facilitate a more socially connected Web where everyone is able to add to and edit the information space (Del Giudice, Della Peruta, \& carayannis, 2014).

Boulos and Wheeler (2007) described the second incarnation of the Web (Web 2.0) as the Social Web, because, in the contrast to Web, its content can be more easily generated and published by users, and the collective intelligence of users encourages and democratic use.

The definition suggested, in more recent times, by Constantinides \& Fountain (2008) states that: Web 2.0 is a collection of open-source, interactive and user-controlled online applications expanding the experience, knowledge and market power of the users as participants in business and social processes. Web 2.0 supports the creation of informal users' networks, facilitating the flow of ideas and knowledge by allowing the efficient generation, dissemination, sharing, and editing/refining of informational content because social media are flexible enough to match our social capabilities, they are responsible for the rise of the new ways of coordinating group action. He also believes that social media have radically altered the way groups communicate, assemble, and manage one another.

The Internet community is expanding at an incredible speed, with profound implications for the emerging economies, not to mention social norms and political systems of countries (Del Giudice, Della Peruta, \& carayannis, 2014) Major part of our lives is now entangled with social media (new media)-mobile phones, laptops, iPods, blogs twitters, SMS, emails, TV screens etc.

Competition among tourism and hospitality business continues to intensify where each sector of the business tends to leverage on its competitive advantage requiring the ability to manage all its service delivery components as well as the marketing media at its disposal (Bornhorst, Ritchie, \& Sheehan, 2010). With The ultimate goal of marketing, and of the relationship marketing approach in particular, is winning new customers and keeping existing customers as such consumers receive messages about products from a variety of sources beyond those originating from marketers. The emergence of the category of online applications commonly described as Web 2.0 presents marketers with a range of new opportunities but also several considerable challenges (Davidson 2011) though building customer engagement in both business and consumer markets requires adaptation of the marketing mix to take advantage of new technologies and tools to better understand and serve customers. Social media provide the opportunity to connect with customers using richer media with greater reach since these digital media not only allows sellers to share and exchange information with their customers but also allows customers to share and exchange information with one another as well (Sashi, 2012).

As such, the aim of the research is to identify the significance of using social media in making choice of products offerings and services by these hotels in Bauchi to domestic tourists as they use social media platforms as tools of referrals, promotion and marketing of services. 


\section{Research Objectives}

1. To assess the use of social media content in empowering customers to make a choice of service in the hospitality industry in Nigeria

2. To asses if social media content influences quality of services offered by Hospitality organizations in Nigeria

3. To asses if quality of service offered affects choices made through social media

\section{Literature Review}

\section{Content of Social Media}

In our day's digital world, there are critical needs to look social in the product contents especially where social media have become an important communication channels for building a connection between organizations and their publics; internal and external publics (DiStaso \& McCorkindale, 2012). Although, 'being social' is a different ball game (Ryan, 2015). The development of digital and mobile gadget fashioned the rise to the creation of social media content and accessing information on the social network platform against the traditional media. It is a mass communication field and most fertile platform for audience to enrich themselves with news stories. Prior to social media, there were other 'private communication' media or public broadcasting media which contents were mainly controlled by few hands. Today, social media has formed a place where members of the societies socialize, not just a means of communication (Miller, et al., 2016). It is evident that social media content provides benefits to new 'Unknowns' as well as 'well-unknown brands' (Kiralova \& Antonin, 2015). These contents vary considerably from place to place, region to region- the description of social media in once society should not be understood rather a regional case. Basically, the social media is not seen as the principal platforms upon which the society is involve in the disseminating of information, but rather as the 'contents that are posted on these platform'- social media is a content of the media content or channel through messages are posted (Miller et al, 2016).

Many scholars have looked at the audience/consumers of product as a 'de facto (co) producers' of social media content through their likes and comments which in turn influences the decision of the organization via their content output (Jonsson \& Ornebring, 2011). Some organizations see these customers both as citizens and consumers due to their roles. The media content here is often referring to the User Generated content, User Created Content and User submitted Story.

They further opined that in some instances, some organizations provide their readers the ability to like and to comment on some stories and recommend content they find valuable. The comments and likes by the consumers are "deskilling", "cheap content" "facilitating redundancies" and "disguising" as everyone is seen as a freelancer in the business of providing content (Harrison, 2010). For Bonin (2016), Jonsson, and Ornebring (2011), this form of social media content (User created content) is sometime seen as unsolicited content where customers are proactive and participating in the package of service delivery and at the same time empowering the consumers to begin and become active in the conversation process.

Social media content about an organization on a particular topic should lead to the public attaching importance to that topic in understanding the organization's reputation (Kaul, 2015) However, since social media are the polar opposite of traditional marketing media, the content on travel blogs should not be promotion oriented but clearly different from the content provided in conventional marketing information (Leung, Law, Hoof, \& Buhalis, 2013).

As we reach beyond the more personal use of social media within friendship and the family we encounter, a large number of institutional settings which are increasingly exposed to new social media, each with its own patterns of usage and consequences (Miller, 2016). Likewise, higher public esteem can be tied to social media content that expresses praise or satisfaction, whereas owner levels of public esteem may be connected to negative content related to blame, hardship, fault-finding, or the denial of responsibility (Kaul, et al., 2015). To 
approach social media in most cases, there are need to begging with enough respect for what has proceeded it because of complexity of communication and its content will offer much of the detail for what social media then becomes (Miller, 2016).

Cabiddu, Carlo, \& Piccoli (2014) observed that, many marketers have realized that by engaging with consumers/customers on social media, especially on Facebook and twitter, where users with such similar engage in sharing information that incautiously form part of the organizational content through likes and comments which are rich in 'internal contextual information' regarding the personal interests, preferences, friendship and relationships. The frequent persistent engagement enables organizations to maintain a continuous dialogue with the organization's customers by exploiting the connectivity, content creation and sharing functionality of social media (Cabiddu, et al, 2014). From the structuring of content in social media, Peter, Chen, Kaplan, Ognibeni, and Pauwels (2013) analyzed how created content drives social media. These contents are characterized into five. They first classified the content along the dimensions of vividness, interactivity, information, entertainment, position and valence. This position the influence of like and comments which are continuously seen on the organizational social media pages asymmetrically. From these, it can be said that content may have three distinct aspects: (1) content quality, subsuming content characteristics (e.g., interactivity, vividness), content domain (e.g., education, entertainment, information), and narrative styles; (2) content valence, subsuming emotions (e.g., anger, anxiety, joy) and tonality (e.g., positive, negative); and (3) content volume, subsuming counts and volumes (Peter, et al, 2013).

Grueskin, Seave and Graves (2011) looked at the 'content' and 'distribution' of the social media, that the coming of digital journalism have created content that are separated into a smaller form, with each story leaving independently of the next. The impact of this is that content which are relevant to a group of audience can easily be assembled. By contrast, publishing social media content means that all the content (audio, video, text, picture, graphic, etc.) will become immediately available to the subscribers that are spread across the world, with little or no cost. Their content is no longer limited to immediate consumers and thus is less restricted by federal regulations. In this case, the social 'media functionalities' enable this affordance a multi-media content creation and interactions in public or semi-public electronic avenue Cabiddu, et al (2014).

The concept of social media content is sometime hard to define the relevance and the negative roles in the creation of such content. Gensler, Volckner, Lui-Thompkins and Wiertz (2013), Pavliceka and Kiralova (2015) posited that the positive content of a social media is more often shared than the negative content despite its complexity of content dissemination. In a broad sense, the democratization of social media content needs further scrutiny as it is perceived to be dangerous (Harvey, 2014).

To get to the point of understanding its effects on 'dialogue and participation in the public sphere' (HAAS, 2005)

H1: User generated content on social media influences quality of service offered by hospitality and tourism businesses in Nigeria.

\section{Internet Penetration}

The emergent of internet penetration in Nigeria was achieved via the coming of the developed nations in the late 1990s. As a nation, the penetration of internet was achieved through Telecommunication Company as it is seen in the developed nations, where telecommunication and defense research establishment contributed immensely to the actualization of internet (Sule, 2016). Umezuruike, Oludele, Kuyoro, Aaron (2015) cited in Sule (2016) stated that there are different indices that led to internet penetration in Nigeria. The major factor among other things is the growing mobile broadband internet, coupled with the increased use of the android phones, smartphones/OIS and some mobile devices. The development of smartphones and personal computer for low income earners in Nigeria makes it that no citizen is left out to digital divide which has brought about the 
increase in internet penetration (Omijeh, Chukueggu, \& Diugwu, 2020). This mean that internet penetration in Nigeria is aided by the emergent of mobile broadband internet.

In recent time, research has shown that most part of Sub-Saharan Africa are currently assimilated with 4G LTE network packages by telecommunication/mobile network providers. These trend towards high subscriptions among users of the internet and allowing the subscribers to actually enjoy standard broadband services as it is

\begin{tabular}{|l|l|l|l|}
\hline Year & Internet Users & Penetration (\%of Pop) & Total Population \\
\hline 2016 & $86,219,965$ & $46.1 \%$ & $186,987.563$ \\
\hline 2015 & $82,094,998$ & $45.1 \%$ & $182,201,962$ \\
\hline 2014 & $75,746,751$ & $42.7 \%$ & $177,475,986$ \\
\hline 2013 & $65,670,2766,276$ & $38 \%$ & $172,816,517$ \\
\hline 2012 & $55,182,852$ & $32.8 \%$ & $168,240,403$ \\
\hline 2011 & $46,560,001$ & $28.4 \%$ & $163,770,669$ \\
\hline 2010 & $38,261,938$ & $24 \%$ & $159,424,742$ \\
\hline 2009 & $31,041,429$ & $20 \%$ & $155,207,145$ \\
\hline 2008 & $23,966,947$ & $15.9 \%$ & $151,115,683$ \\
\hline 2007 & $9,962,224$ & $6.8 \%$ & $147,152,502$ \\
\hline 2006 & $7,947,035$ & $5.5 \%$ & $143,318,011$ \\
\hline 2005 & $4,955,023$ & $3.5 \%$ & $139,611,303$ \\
\hline 2004 & $1,749,576$ & $1.3 \%$ & $136,033,321$ \\
\hline 2003 & 740,569 & $0.6 \%$ & $132,581,484$ \\
\hline 2002 & 414,185 & $0.3 \%$ & $129,246,283$ \\
\hline 2001 & 113,289 & $0.1 \%$ & $126,014,935$ \\
\hline 2000 & 78,740 & $0.1 \%$ & $122,876,723$ \\
\hline
\end{tabular}

Source: Internet Live Stats (www.InternetLiveStats.com)

been experience by other part of the developed world.

Table 1: Internet Penetration in Nigeria

From the above table, it is observed that the penetration of internet in Nigeria from 2000 to 2016 is on the increase. Also, it is evident that as internet users increase on yearly bases, penetration also increases. It further ascertains that the penetration of internet was as a result of acquired and installed standard broadband.

\section{Hospitality and Tourism services}

Tourism and Hospitality services cannot be easily described, however the variation from one benefit to another being that most times the services have unique fingerprints and their performance must be nuanced by individual customer preferences another (Mok, Sparks , \& Kadampully, 2001). It thus comes to designing personalized products. In furtherance to that, the World Trade Organization (2015) sees tourism and travelrelated services to include services provided by hotels and restaurants (including catering), travel agencies and tour operator services, tourist guide services and other related services. 
Table 2: Name of Hotels in Bauchi State

\begin{tabular}{|c|c|c|c|c|}
\hline $\begin{array}{l}\mathrm{S} / \\
\mathrm{N}\end{array}$ & Names Of Hotels & $\begin{array}{l}\text { No. } \quad \text { Of } \\
\text { Rooms }\end{array}$ & $\begin{array}{l}\text { Hotel Grading And } \\
\text { Classification }\end{array}$ & Address \\
\hline & Benco Hotels & 35 & 1 Star & Rafin Zurfi, Bauchi \\
\hline 2 & River Edge Resort & 36 & 2 Stars & $\begin{array}{c}\text { No. } 5 \text { Hinna Close, Gra, } \\
\text { Bauchi }\end{array}$ \\
\hline 3 & Bagari Suite & 16 & 2 Stars & Dass Road, Bauchi \\
\hline 4 & Azizia Hotel & 17 & 1 Star & New Gra Bauchi \\
\hline 5 & De Crown Hotel & 16 & No Rating & Rafin Zurfi, Bauchi \\
\hline 6 & Janvic Guest Inn & 14 & No Rating & Murtala Mohd Way, Bauchi \\
\hline 7 & Hotel Sindaba & 41 & 1 Star & $\begin{array}{c}\text { No. } 1 \text { Hinna Close, Gra, } \\
\text { Bauchi }\end{array}$ \\
\hline 8 & Kapoo Suites And Hotels & 17 & 1 Star & Along Jos Road, Bauchi \\
\hline 9 & New Trafford Hotel & 12 & 1 Star & Gwallameji Dass Road, Bauch \\
\hline 10 & Alti Guest Inn & 16 & No Rating & Rafin Zurfi, Bauchi \\
\hline 11 & Bubes Suite And Hotels & 36 & 1 Star & Gwallameji, Bauchi \\
\hline 12 & Executive Nest & 26 & 2 Stars & Maiduguri Bye-Pass, Bauchi \\
\hline 13 & Pali Suite & 42 & 1 Star & Gra, Bauchi \\
\hline 14 & Jolly Guest Inn & 20 & No Rating & New Gra, Bauchi \\
\hline 15 & Kainuwa Suite And Hotels & 40 & No Rating & New Gra, Bauchi \\
\hline 16 & Rahama City Suite & 11 & 1 Star & New Gra, Bauchi \\
\hline 17 & Wvpp Hotel And Suites & 14 & No Rating & New Gra, Bauchi \\
\hline 18 & Villa Garden And Suites & 31 & 1 Star & Gra, Bauchi \\
\hline 19 & Hazibal Suites And Hotels & 42 & 3 Stars & New Gra, Bauchi \\
\hline
\end{tabular}


Proceeding of the $7^{\text {th }}$ International Conference on Hospitality and Tourism Management, Vol. 5, Issue 1, 2020, pp. 65-85

\begin{tabular}{|c|c|c|c|c|}
\hline 20 & Sahab Suites & 7 & No Rating & New Gra, Bauchi \\
\hline 21 & D.E.C. Guest House & 33 & 1 Star & Kaduna Road Old Gra, Bauchi \\
\hline 22 & Jamil Guest Palace & 60 & 3 Stars & Behind Dass Park, Bauchi \\
\hline 23 & Larema Hotels And Suites & 44 & 2 Stars & Behind Dass Park, Bauchi \\
\hline 24 & Faria Suites & 24 & 3 Stars & New Gra, Bauchi \\
\hline 25 & Cfa Hotel & 38 & 1 Star & Gombe Road, Bauchi \\
\hline 26 & Reme Guest Inn & 16 & No Rating & Tudun Salmanu, Bauchi \\
\hline 27 & Chaba Guest Inn & 34 & No Rating & Maiduguri Road, Bauchi \\
\hline 28 & Awalah Hotel & 132 & Folded Up & Ningi Road, Bauchi \\
\hline 29 & Zaranda Hotel & 100 & 2 Stars & Jos Road, Bauchi \\
\hline 30 & Wikki Resort & 12 & 3 Stars & Yakubun Bauchi Road, Bauchi \\
\hline 31 & Terminus Hotel & 34 & No Rating & Jos Road, Bauchi \\
\hline 32 & Polycon Guest Inn & 31 & 2 Stars & Sa'Adu Zungur, Road, Bauchi \\
\hline 33 & Chartwell Hotel & 34 & 3 Stars & $\begin{array}{c}\text { By Isa Yuguda House Jos } \\
\text { Road, Bauchi }\end{array}$ \\
\hline 34 & Destination Hotel & 53 & 2 Stars & $\begin{array}{c}\text { Tafawa Balewa Way Gra, , } \\
\text { Bauchi }\end{array}$ \\
\hline 35 & Sight Suites And Hotel & 10 & No Rating & $\begin{array}{c}\text { Off Sunday Awoniyi Road, } \\
\text { Bauchi }\end{array}$ \\
\hline 36 & Focus Guest Inn & 30 & No Rating & Gra, Bauchi \\
\hline 37 & Command Guest House & 51 & 3 Stars & Ningi Road By Awalah, Bauchi \\
\hline 38 & Khairan Guest Palace & 35 & 1 Star & Murtala Mohd Way, Bauchi \\
\hline 39 & Ezmada Guest Inn & 12 & No Rating & Tudun Wada Area, Bauchi \\
\hline 40 & Jarmari Guest Inn & 15 & No Rating & Gra Stella Road, Bauchi \\
\hline
\end{tabular}


Alamai et al/Social Media Content and Service Delivery Empowerment in Hospitality Businesses in Nigeria

\begin{tabular}{|c|c|c|c|c|}
\hline 41 & Nkamglo Hotel & 24 & & Tudun Wada Area, Bauchi \\
\hline 42 & $\begin{array}{c}\text { Royal Neighbourhood } \\
\text { Resort }\end{array}$ & 20 & No Rating & Murtala Moh'D. Way, Bauchi \\
\hline 43 & Obuna Royal Hotel & 48 & 1 Star & Murtala Moh'D. Way, Bauchi \\
\hline 44 & Express Hotel & 12 & No Rating & $\begin{array}{c}\text { Tudun Wada Bayan Gari, } \\
\text { Bauchi }\end{array}$ \\
\hline 45 & Suoreme Guest Inn & 8 & No Rating & $\begin{array}{c}\text { Tudun Wada Bayan Gari, } \\
\text { Bauchi }\end{array}$ \\
\hline 46 & Edipet Guest Inn & 8 & No Rating & $\begin{array}{c}\text { Tudun Wada Bayan Gari, } \\
\text { Bauchi }\end{array}$ \\
\hline 47 & Jubilee Hotel & 14 & No Rating & $\begin{array}{c}\text { Tudun Wada Bayan Gari, } \\
\text { Bauchi }\end{array}$ \\
\hline 48 & Giden Jummai & 19 & No Rating & $\begin{array}{c}\text { Tuddun Wada Bayan Gari, } \\
\text { Bauchi }\end{array}$ \\
\hline 49 & Extension Hotel & 18 & No Rating & Yelwan Tudu, Bauchi \\
\hline 50 & Premier Hotel & 60 & No Rating & Yelwan Tudu, Bauchi \\
\hline 51 & Teachers Hotel & 22 & No Rating & $\begin{array}{c}\text { Teachers House Yandoka Rd, } \\
\text { Bauchi }\end{array}$ \\
\hline 52 & Rendezvous Guest Inn & 17 & No Rating & $\begin{array}{c}\text { Tudun Wada Bayan Gari, } \\
\text { Bauchi }\end{array}$ \\
\hline 53 & Tropical Guest Inn & 20 & No Rating & $\begin{array}{c}\text { Tudun Wada Gayan Gari, } \\
\text { Bauchi }\end{array}$ \\
\hline 54 & Blue Sport Guest Inn & 20 & No Rating & $\begin{array}{c}\text { Tudun Wada Gayan Gari, } \\
\text { Bauchi }\end{array}$ \\
\hline 55 & Village Inn & 9 & No Rating & Yelwan Makaranta, Bauchi \\
\hline 56 & Aliss Hamdala Hotel & 35 & No Rating & Ibb Square, Bauchi \\
\hline 57 & New State Hotel & 15 & No Rating & Old Gra, Bauchi \\
\hline
\end{tabular}


Proceeding of the $7^{\text {th }}$ International Conference on Hospitality and Tourism Management, Vol. 5, Issue 1, 2020, pp. 65-85

\begin{tabular}{|c|c|c|c|c|}
\hline 58 & Peoples Club & 14 & No Rating & Dass Park Area, Bauchi \\
\hline 59 & Jubilee Extention & 18 & No Rating & Yelwa, Bauchi \\
\hline 60 & Dadin Kowa & 18 & No Rating & $\begin{array}{l}\text { Tudun Wada Bayan Gari, } \\
\text { Bauchi }\end{array}$ \\
\hline 61 & Kogi Guest Inn & 8 & No Rating & $\begin{array}{l}\text { Tudun Wada Bayan Gari, } \\
\text { Bauchi }\end{array}$ \\
\hline 62 & Salama Holiday Inn & 15 & No Rating & Kaduna Street, Bauchi, Bauchi \\
\hline 63 & Rock View & 9 & No Rating & $\begin{array}{l}\text { Tudun Wada Bayan Gari, } \\
\text { Bauchi }\end{array}$ \\
\hline 64 & Sogiji Hotel & 25 & Folded Up & Ran Road, Bauchi, Bauchi \\
\hline 65 & Tolu Guest Inn & 20 & No Rating & Yelwan Tudu, Bauchi \\
\hline 66 & Ambassador Hotel Inn & 5 & No Rating & Yelwan Tudu, Bauchi \\
\hline 67 & Hummy Hotel & 14 & No Rating & Yelwan Tudu, Bauchi \\
\hline 68 & Kaduna Hotel & 9 & No Rating & Rafin Zurf, Bauchi \\
\hline 69 & Peoples Hotel & 48 & No Rating & Dass Park Area, Bauchi \\
\hline 70 & Queen'S Palace & 26 & No Rating & $\begin{array}{l}\text { Tudun Wada Bayan Gari, } \\
\text { Bauchi }\end{array}$ \\
\hline 71 & Rendey-Vours Guest Inn & 26 & No Rating & Murtala Mohd Way, Bauchi \\
\hline 72 & Yarmari Guest Inn & 8 & No Rating & Adaти Јитbа Road, Bauchi \\
\hline 73 & Royal Abey & 16 & No Rating & Gra, Bauchi \\
\hline 74 & Sarauniya Suite & 30 & No Rating & Gra, Bauchi \\
\hline 75 & Dec Guest House & 30 & 1 Star & Kaduna Street, Bauchi \\
\hline 76 & Kanglo Guest Inn & 20 & No Rating & Maiduguri Bye-Pass, Bauchi \\
\hline
\end{tabular}




\begin{tabular}{|l|l|l|l|l|}
\hline 77 & Collins Vest Hotel & 15 & No Rating & Azare, Bauchi \\
\hline 78 & Katagum Suite & 20 & No Rating & Azare, Bauchi \\
\hline 79 & Jimbros & 22 & No Rating & Azare, Bauchi \\
\hline 80 & Watal Hotel & 20 & No Rating & Tafawa Balewa, Bauchi \\
\hline 81 & Amurzymam Hotel & 15 & 1 Star & Rinji, Toro, Bauchi \\
\hline 82 & Yimir Hotel And Suites & 20 & 3 Stars & New Gra, Bauchi \\
\hline 83 & Bagari Suites & 25 & 3 Stars & Opposite Bsadp Hq, Bauchi \\
\hline
\end{tabular}

Source: Bauchi State Tourism Board (2019)

\section{Service Delivery concept}

Getting a precise definition of the concept of service is not easily grasped as different sectors ascribe meaning to how they perceive it to be. However, for this study we will use that given by Atsutsey and Tandoh-Offin (2013) in which they see services through the perspectives of how they are produced, consumed, and evaluated with service quality based on consumer perceptions of the outcome of the experience garnered.

Advardsson, Tronvoll, \& Gruber (2011) argue that competitive advantage is primarily created through operant resources, rather than through operand resources, because knowledge and skills operate on resources to solve problems, fulfill needs, and produce a favorable customer experience (Vargo \& Lusch, 2004). Service-dominant logic thus establishes a framework of reciprocal service provision in which value is dynamically co-created with customers as either "value-in-use" (Vargo and Lusch ,2004) or "value-in-context" (Vargo, 2008). Furthermore, Edvardson et al (2011) deem it that service exchanges and stakeholders roles are dynamic in any adaptive service systems such as tourism and hospitality where providers should design service systems that are capable of adapting to the changes induced by customers and other actors within the system, as well as by the social forces outside the system. Customers, employees and other actors interact, innovate, and learn especially through modern IT technologies and system (Edvardson et al 2011). Equally, Gummesson (2014) asserts that suppliers can make a value proposition and then see what the customers do which is common to hospitality where you can consider cities or countries as value propositions from which visitors select their own combination of what they want to do and see; the value of the place is determined by the visitors or the customer. In a synthesis of service innovation theories, Wittel, Snyder, Gustafsson, Fombelled, \& Kristensson (2016) are of the view that authors of service and innovation describe it as being a creation with a value proposition in mind, which enables the user of the service to create value for themselves or their community. Quality in service however is defined by Whitfield and Webber (2010) as the consumer's overall impression of the relative inferiority/superiority of the organization and its services. A notable change occurring in the tourism industry is the consumer's growing orientation towards an emphasis and demand for 'quality of experience.' More than ever before, operators in the tourism industry recognize that it is the 'high quality service experience' that makes a tourist patronize a particular establishment in the tourism business. Consequently, the industry is becoming more competitive in the 'race for a higher level of service.' As one industry executive, has put it forcefully (Chon 1999). This has given rise to customer engagement behaviours which result from motivational drivers including word-of-mouth activity, customer-to-customer (C2C) interactions and/or blogging activity having behavioral manifestations that have a brand- or firm-focus, beyond purchase, (Brodie, Hollebeek, Biljana, and Ilic, 2011) resulting from motivational drivers of the quality services offered by the organizations 
which includes focal service relationships which occurs under a specific set of context dependent conditions generating differing CE levels; and exists as a dynamic, iterative process within service relationships that cocreate value (Brodie et al 2011)

\section{Social Media and Consumer Empowerment}

Engaging with customers is one of the most significant shifts in marketing brought about by social media (Harrigan \& Miles, 2014) because more consumers are active on social media, marketers' use of these tools such as Facebook, Twitter, YouTube, LinkedIn, Instagram and Pinterest. However, the nature of the Internet through Web 2.0, is that almost all websites are becoming 'social'; that is, they allow interaction (Chau and Xu, 2012). Customers can post comments, ratings, reviews, and share all these across their own social networks. Thus, sites like Amazon, TripAdvisor, Urban spoon, Yelp, the entire Google network and many other peer-topeer websites such as blogs, micro blogs, wikis, podcasts, photo sharing, video sharing and social bookmarking can be viewed as social media technologies and thus as potential empowerment networks (Harrigan \& Miles 2014). Empowerment is a phenomenon common to the internet where Labrecque, Esche, Mathwick, Novak, and Hofacker (2013) defines it as the dynamic process of gaining power through action by changing the status quo in current power balances. and, this is gained through the internet's ability of increased information access, choice and options through voice and exit (Labrecque et al 2013). Which goes to say the diffusion of web 2.0 technologies and their traits influences the emergence and evolution of consumer empowerment (Kozinets, De Valk, Wojnicki, \& Wilner, 2010). Thus the shift in information based power towards the consumer has given him the affordability related to interactivity and enhanced psychological sense of control which empowers him by providing an outlet for self-expression, individual reaction, e-WOM greater responses, consumers becoming experts because of the consumer generated content in social media (Labrecque et al 2013). This thus goes to show that the rise of social media and the customer no longer plays a passive role between him and the tourism /hospitality business being that information about competitive products are available at his finger tips on mobile devices where opinions about services are expressed and shared with larger audiences and making it difficult for the businesses to manage whose net effect is more power to consumers (Malthouse, Haenlein, Skeira, Wege, and Zhang (2013). Furthermore, Sashi (2012) added that during the process of customer engagement it focuses on market orientation through active involvement of customers from generating intelligence on their changing needs, helping organizations respond to those needs making the process of value creation shift from a productand firm-centric view to personalized customer experiences with informed, networked, empowered, and active customers increasingly co-creating value with the organization for effective service delivery.

H2: Social media empowers the customers in choice of services offered by hospitality and tourism businesses in Nigeria

\section{Theoretical Framework}

This study is anchored on Diffusion of innovation Theory. Diffusion of Innovation (DOI) Theory was propounded by E.M. Rogers in 1962. The theory is seen as one of the oldest social science theories and it is also referred to as the Adoption of New Ideas or Media. It seeks to explain how, over time, a new idea, product, or practice is adopted by members of a given culture through a specific population or social system. Diffusion is the process by which an innovation is communicated through certain channels within a period of time among the members of a social system while innovation is an 'idea, practice, or object that is perceived to be new by an individual or other unit of adoption' (Twente, 2017). Diffusion of innovation theory envisages that media as well as interpersonal contacts offer information and influence opinion and judgment. The theory believes that "innovation (adoption of new idea, behaviour or product) does not take place separately in a social system, but rather it provides platform for some individual in the society to adopt the innovation more than the other. Researchers have over the years tried to elucidate how innovation of diffusion research has attempted to explain the variables that influence how and why users adopt a new information medium, such as the Internet. Rogers (1995) cited in Boston (2019) argued that occurrence of innovation consists of four stages: invention, diffusion (or communication) through the social system, time and consequences. This means the information flows 
through networks and the nature of networks and the roles opinion leaders play in them determine the likelihood that the innovation will be adopted. This viably indicates that the characteristics of the target population who will help in adopting the innovation most be understood.

The Diffusion of Innovation Theory is used in this research to further explain the factors influencing Service Delivery Empowerment in Hospitality Businesses in Nigeria.

\section{Methodology}

The study used a quantitative technique where structured questionnaire was developed and administered personally by the researchers to SIX 3-star hotels out of 82 hotels registered with Bauchi State Tourism Board North East Nigeria and the hotels were selected based on the grading and classification system of the State Tourism Board (Star rating). Also, only 6 hotels were of 3 stars namely: Bagari suites, Chartwell Hotel, Hazibal Hotel and Suites, Command guest House, Wikki Hotels and Yimir Hotel and Suites. Equally, the hotels at the time of the research that had at least 3 active social media platforms in use. The research work was conducted in 6 months with the aim of identifying significance of using social media in making choice of products offerings and services offered by these hotels to domestic tourists as they use social media platforms as tools of referrals, promotion and marketing of services and the results were analyzed using mean percentage and hypothesis raised were tested using chi square.

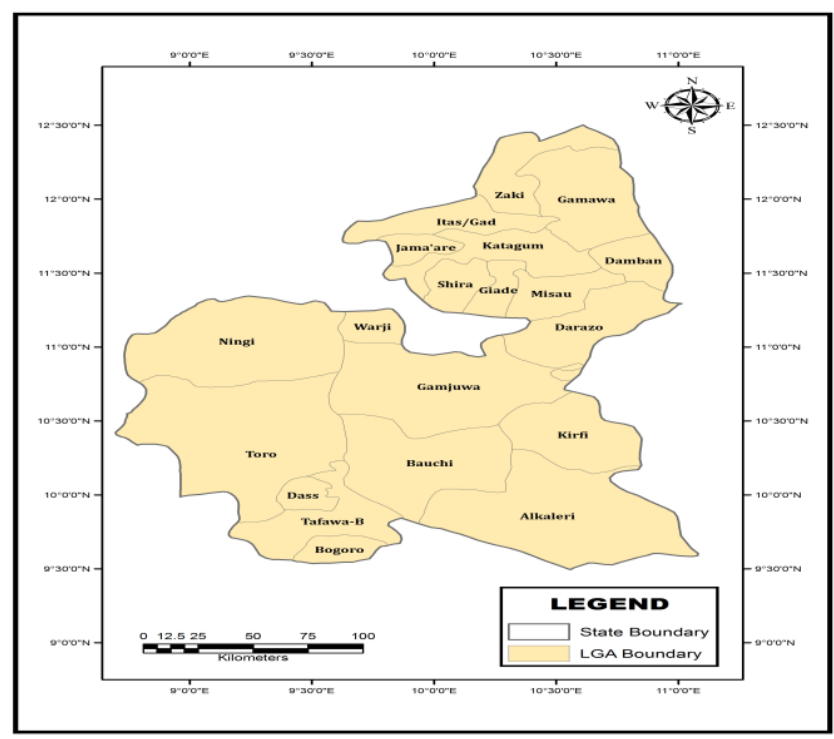

Figure 1: Area of study (Map of Bauchi state)

Source: Geospatial Analysis Mapping and Environmental Research Solutions (2018)

Table 3: Demographic Analysis

\begin{tabular}{|l|l|l|l|l|}
\hline & N & Sum & Mean & Std. Deviation \\
\hline Age of Participants & 100 & 315.0 & 3.150 & 1.2258 \\
Categories of Customers & 100 & 201.0 & 2.010 & 8102 \\
Gender of Participants & 100 & 162.0 & 1.620 & 4878 \\
Valid N (listwise) & 100 & & & \\
\hline
\end{tabular}

Source Field Survey (2019) 
From the demographic table above, it is evident that the total population size of the respondents was 100 with a cumulative mean ranging from 3.1 for age of participants to 2.0 for categories of customers and 1.6 for Gender. However, the frequency of Reponses per variable of demography are in the tables below

Table 4: Age of Respondents

\begin{tabular}{|ll|l|l|l|l|}
\hline & Frequency & Percent & Valid Percent & $\begin{array}{l}\text { Cumulative } \\
\text { Percent }\end{array}$ \\
\hline Valid & $19-28$ & 10 & 10.0 & 10.0 & 10.0 \\
& $29-38$ & 21 & 21.0 & 21.0 & 31.0 \\
$39-48$ & 30 & 30.0 & 30.0 & 61.0 \\
$49-58$ & 22 & 22.0 & 22.0 & 83.0 \\
$59-A b o v e$ & 17 & 17.0 & 17.0 & 100.0 \\
Total & 100 & 100.0 & 100.0 & \\
\hline
\end{tabular}

Source: Field Survey (2019)

From above table, it indicates that out of 100 respondents, $30 \%$ of the tourist are within the age bracket of 39-48 respondents, $22 \%$ represent $49-58$ tourists while $10 \%$ of the respondents which represent the tourists are within the age of 19-28. This reveals that tourists within the age of 29-58 visit hotels in the state.

Table 5: Categories of Customers

\begin{tabular}{|ll|l|l|l|l|}
\hline & & Frequency & Percent & Valid Percent & $\begin{array}{l}\text { Cumulative } \\
\text { Percent }\end{array}$ \\
\hline Valid & Business Tourist & 32 & 32.0 & 32.0 & 32.0 \\
& Leisure Tourist & 35 & 35.0 & 35.0 & 67.0 \\
Sports Tourist & 33 & 33.0 & 33.0 & 100.0 \\
Total & 100 & 100.0 & 100.0 & \\
\hline
\end{tabular}

Source: Field Survey (2019)

Table 5 above represents the categories of customers in Bauchi state. The table indicates that $35 \%$ of Leisure tourists visit the hotels follow by the Business tourist with $32 \%$. This simply mean that Bauchi state has more of the Leisure tourist compare to Business tourists and Sport tourist. 


\begin{tabular}{|ll|l|l|l|l|}
\hline & & Frequency & Percent & Valid Percent & $\begin{array}{l}\text { Cumulative } \\
\text { Percent }\end{array}$ \\
\hline Valid & Male & 38 & 38.0 & 38.0 & 38.0 \\
& Female & 62 & 62.0 & 62.0 & 100.0 \\
& Total & 100 & 100.0 & 100.0 & \\
\hline
\end{tabular}

Source: Field Survey (2019)

Table 6 shows the gender of the respondents. $62 \%$ of female which form the total population were represented while $38 \%$ of the male tourists were also represented. This was an indication that there are more female tourists who pay visit to the hotels within the state.

\section{Results and Findings}

Table 7: Social Media Platforms used by Hotels

\begin{tabular}{|lll|l|l|l|l|}
\hline & & Frequency & Percent & Valid Percent & $\begin{array}{l}\text { Cumulative } \\
\text { Percent }\end{array}$ \\
\hline & $\begin{array}{l}\text { One Social } \\
\text { Platforms }\end{array}$ & Media & 2 & 37.9 & 37.9 & 37.9 \\
$\begin{array}{l}\text { Two Social } \\
\text { Platforms Media }\end{array}$ & 1 & 20.7 & 20.7 & 58.6 \\
Valid Social & Media & 2 & 41.4 & 41.4 & 100.0 \\
Platforms & & 5 & 100.0 & 100.0 & \\
Total & & 5 & & & \\
\hline
\end{tabular}

Source: Field Survey (2019)

Results from the table above has it that two of the respondents, Chart Well and Hazibal Suites, representing 40\% of the total responses were using only one social media platform which is online reviews to display their adverts and other notifications. However, a respondent, Command Guest House, representing $20 \%$ of responses is using two social media platforms which are WhatsApp and online reviews to display their adverts and other notifications. While two respondents Bagari Suites and Wikki, representing 40\% of the responses were using four (4) social media platforms to display their adverts and other notifications. Facebook, twitter, WhatsApp and online reviews were used in Bagari Suites, while Wikki adopted twitter, Instagram, WhatsApp and online reviews platforms. Of all these social media platforms, online reviews are the most used social media medium that is common among all the respondents.

\section{Decision Rule}

For 5-point likert scale, the degrees of agreement or disagreement to the averages of the following variables are; Not agrees: $0.5-1.49$, Moderately agreed: $1.5-2.49$, Agreed: $2.5-3.49$, Highly agreed: $3.5-4.49$ while categories fall within 4.5 and above were perfectly agreed. 
Table 8: Descriptive Statistics of respondents

\begin{tabular}{|l|l|l|l|}
\hline & N & Mean & Std. Deviation \\
\hline Quality of Service Offered & 100 & 2.62 & 1.399 \\
Customer Empowerment & 100 & 2.59 & 1.842 \\
Services delivery & 100 & 3.14 & 1.125 \\
Sustaining the Patronage & 100 & 3.41 & 1.659 \\
Valid N (list wise) & 100 & & \\
\hline
\end{tabular}

Source: Field survey (2019)

Results presented in the table above showed that the mean ratings of the respondent's responses on five (5) points which were outside the boundary limit of 2.50 and above on a 5-point rating scale. This indicated that the social media platform has an effect on the quality of services offered (mean $=2.62>2.50$ ), customers were empowered on social media $($ mean $=2.59>2.50)$, social media has affected the service delivery $(\mathrm{mean}=3.14>$ $2.50)$ and social media sustained the patronage of the organization (mean $=3.41>2.50$ ).

\section{$\underline{\text { Hypothesis } 1}$}

H0: User generated content on social media has no influences on the quality of services offered by hospitality and tourism business in Nigeria.

H1: User generated content on social media has an influence on the quality of services offered by hospitality and tourism business in Nigeria.

Table 9: Chi square of hypothesis 1

\begin{tabular}{|l|l|l|l|l|}
\hline Model & R & R Square & $\begin{array}{l}\text { Adjusted } \\
\text { Square }\end{array}$ & $\begin{array}{l}\text { Std. Error of } \\
\text { the Estimate }\end{array}$ \\
\hline 1 & .664 & .441 & .438 & .168 \\
\hline
\end{tabular}

Source: Field Survey (2019)

a. Dependent Variable: Social Media Platform

b. Predictors: (Constant) Quality of service offered 


\begin{tabular}{|c|c|c|c|c|c|}
\hline Model & $\begin{array}{l}\text { Sum } \\
\text { Squares }\end{array}$ & of $\mathrm{Df}$ & $\begin{array}{l}\text { Mean } \\
\text { Square }\end{array}$ & $F$ & Sig. \\
\hline $\begin{array}{l}\text { Regression } \\
\text { Residual } \\
\text { Total }\end{array}$ & $\begin{array}{l}16.340 \\
36.833 \\
53.172\end{array}$ & 27 & $\begin{array}{l}16.340 \\
1.364\end{array}$ & 11.978 & $.002^{\mathrm{b}}$ \\
\hline
\end{tabular}

Source: Field Survey (2019)

$\mathrm{R}$, the correlation coefficient showed strong relationship between the social media and quality of services offered $(\mathrm{R}=0.664)$. $\mathrm{R}$ - square, the coefficient of determination is 0.441 . This showed that $44.1 \%$ of the total variation is explained by the changes in the independent variable. That is to say, social media platform has an impact on the quality of services offered by hospitality and tourism business in Nigeria with $44.1 \%$.

A simultaneous regression analysis was carried out to assess the influence of these variables. Study shows that when these variables were combined, hospitality and tourism business in Nigeria will got enhance significantly $(\mathrm{P}=0.002<0.05)$.

$\mathrm{R}$ - square change is $43.8 \%$. This showed that there is a high relation between social media platform and the quality of services offered indicating an influence of social media and the quality of services offered, hence null hypothesis is rejected. This is confirmed by the result in ANOVA as the ' $\mathrm{P}$ ' - value is less than 0.05 ( $\mathrm{P}=0.002$ $<0.05)$.

\section{$\underline{\text { Hypothesis } 2}$}

H0: Absence of quality of service can affect the customers' patronage of the hotels.

H1: Absence of quality of service does not affect customers patronage of the hotels

\section{$\underline{\text { Hypothesis } 3}$}

H0: Social media do not empower the customers in the choice of services offered by hospitality and tourism business in Nigeria.

H1: Social media empowers the customers in the choice of services offered by hospitality and tourism business in Nigeria.

Table 11: Chi Square of Hypothesis 3

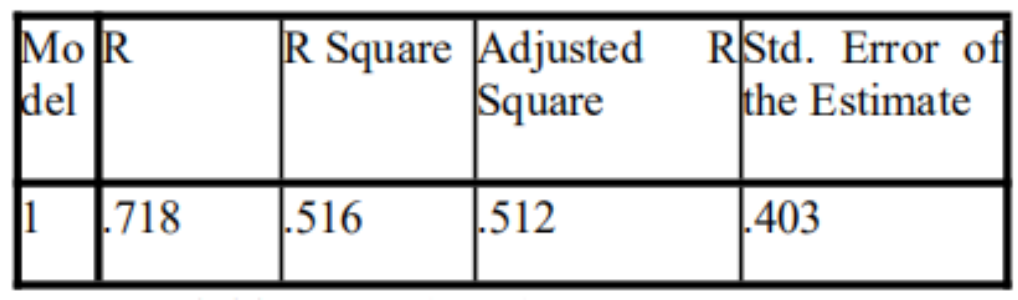

Source: Field Survey (2019) 
a. Dependent Variable: Number of Social Media Platforms

b. Predictors (Constant) Customer Empowerment

Table 12: Anova

\begin{tabular}{|l|ll|l|l|l|l|}
\hline Model & $\begin{array}{l}\text { Sum } \\
\text { Squares }\end{array}$ & of & Mf & Mean Square & F & Sig. \\
\hline Regression & 53.168 & 1 & 53.168 & 46.314 & 000 \\
1 & Residual & 31.004 & 27 & 1.148 & & \\
Total & 53.172 & 28 & & & \\
\hline
\end{tabular}

Source; Field Survey (2019)

The coefficient of correlation, $\mathrm{R}$, showed a strong relationship between the social media and the customer's empowerment in the choice of services offered $(\mathrm{R}=0.718)$. $\mathrm{R}$ - Square, the coefficient of determination is 0.516 . This showed that $51.6 \%$ of the total variation is explained by the changes in the independent variable. That is to say, social media has an impact on the customer's empowerment in the choice of services offered by hospitality and tourism business in Nigeria with $51.6 \%$.

A simultaneous regression analysis was carried out to assess the influence of these variables. Study shows that when social media is improved customers will get empowered and hospitality and tourism business in Nigeria will got enhance significantly $(\mathrm{P}=0.000<0.05)$.

$\mathrm{R}$ - Square change is $51.2 \%$. This showed that there is a high relation between social media platform and the customer's empowerment in the choice of services offered indicating an influence of social media and the customer's empowerment in the choice of services offered, hence null hypothesis is rejected. This is confirmed by the result in ANOVA as the ' $\mathrm{P}$ ' - value is less than $0.05(\mathrm{P}=0.000<0.05)$.

\section{Summary of Findings}

From the analysis, the findings of the study have revealed that of all these social media platforms, online reviews are the most used social media platform that is common among all the respondents.

Also User Generated Content has influence on service delivery which agrees with Labrecque et al (2013) assertion that it's the dynamic process of gaining power through action by changing the status quo in current power balances and, this is gained through the internet's ability of increased information access, choice and options through voice and exit.

There is also a finding that there is a high positive relationship between customers' empowerment and choice of services through use of social media which is in agreement with (Whitfield \& Webber, 2010) as the consumer's overall impression of the relative inferiority/superiority of the organization and its services. A notable change occurring in the tourism industry is the consumer's growing orientation towards an emphasis and demand for 'quality of experience.' More than ever before, operators in the tourism industry recognize that it is the 'high quality service experience' that makes a tourist patronize a particular establishment in the tourism business. Consequently, the industry is becoming more competitive in the 'race for a higher level of service. 


\section{Discussion}

From the findings of the research, it was highlighted that the selected hotels make use of mine User Generated Content for their daily interactions with customers as well as using it as a form of data mining strategy which agrees with Jonsson and Ornebring, (2011) views that many scholars have looked at the audience/consumers of product as a 'de facto (co) producers' of social media content through their likes and comments which in turn influences the decision of the organization via their content output while some organizations see these customers both as citizens and consumers due to their roles.

The second findings shows customers empowerment is of positive impact on service delivery by hotels in Bauchi through their interactions and influence which also agrees with the arguments of Sashi (2012) that during the process of customer engagement it focuses on market orientation through active involvement of customers from generating intelligence on their changing needs, helping organizations respond to those needs making the process of value creation shift from a product- and firm-centric view to personalized customer experiences with informed, networked, empowered, and active customers increasingly co-creating value with the organization for effective service delivery. In the last two decades, there has been a tremendous increase in penetration of the internet into remote areas and towns across Nigeria as a country. Likewise, it was further buttressed by Omijeh, Chukueggu, and Diugwu (2020) that the development of smartphones and personal computer for low income earners in Nigeria makes it that no citizen is left out to digital divide which has brought about the increase in internet penetration This means that internet penetration in Nigeria is aided by the emergent of mobile broadband internet.

Furthermore, looking at the number of registered hotels in the state and those with 3 star rating, the availability of quality service options is low thereby restricting customers choices to a few while limiting active competition with conditional selection of services which is at variance with the arguments of Malthouse, Haenlein, Skeira, Wege, and Zhang (2013) that the rise of social media and the customer no longer plays a passive role between him and the tourism /hospitality business being that information about competitive products are available at his finger tips on mobile devices where opinions about services are expressed and shared with larger audiences and making it difficult for the businesses to manage whose net effect is more power to consumers.

\section{Conclusion}

The race for service has no finish line. As the race progresses, the finish line moves further away. Those who do not run fast enough will fall behind. Therefore, the hotels need to take advantage of the Web 2.0 (Social Media Platforms) and interact fully with the array of their customers for better productivity while also maximizing profit and retaining customers. Equally, in adopting new idea, behaviour or product hotels are expected to consider that they are not in a separate social system, but rather in a system with different platforms within the society they conduct their activities to innovate more than their competitors. Equally, worth noting is consumers crave and desire for high quality service and product offerings which makes hotels to innovate on a continuous circle.

\section{Suggestions for further research}

In making suggestions for further research, the researchers will recommend that the scope should be expanded to cover the whole of Nigeria as a country as the researchers limited, they scope to only one state out of 36 states of the federation called Nigeria.

\section{Limitations of the study}

The number of respondents compared to time spent conducting the research as some were not willing to fill in the questionnaire which if the sample was like a thousand respondents it would have generated a lot of data. 


\section{References}

Advardsson, B., Tronvoll, B., \& Gruber, T. (2011). Expanding Understanding of Service Exchange and Value Co-creation: A Social Construction Approach. 39(2), 327-339.

Allen, D. S. (2008). The Trouble with Transparency: The challenge of doing Journalism Ethics in a surveillance. Journalism Studies, 9(3), 323-340

Anderson, P. (2007). All That Glisters is not Gold- Web 2.0 and the Librarian. Journal of Librarianship and Information, 39(4), 195-198.

Atsutsey, R and Tandoh-Offin,P. (2013) Developing Service Delivery Standards for the Hospitality Industry in Ghana. European Journal of Business and Management www.iiste.org ISSN 2222-1905 (Paper) ISSN 22222839 (Online) Vol.5, No.29, 2013.

Bornhorst, T., Ritchie, J. B., \& Sheehan, L. (2010). determinants of Tourism Success for DMOs \& Destinations: an Emphirical Examination of Stakeholder's Perspectives. 31(5), 572-589.

Bonin, G. A. (2016) Organization Factors Influencing Journalists' Use of User Generated Content: A Case of Canadian Radio Newsroom. The Radio Journal- International Studies in Broadcast \& Audio Media, 14 (1), 109 122

Boston. (2019, September 10). Diffusion of Innovation Theory. Retrieved from Boston University: https://sphweb.bumc.bu.edu/otlt/mph-modules/sb/behavioralchangetheories/behavioralchangetheories4.html

Boulos, M. N., \& Wheeler, S. (2007). The Emerging Web 2.0 Social Software: An Enabling Suite of Social Technologies in Health and Health Care Education. Health Information \& Libraries Journal, 24(1), 2-23.

Brodie,J. L., Hollebeek,D. L., Biljana J. B., and Ilic, A. (2011) Customer Engagement: Conceptual Domain, Fundamental Propositions, and Implications for Research. Journal of Service Research 14(3) 252-271.

Cabiddu, F., Carlo, M. D., \& Piccoli, g. (2014). Social Media Affordances: Enabling Customer Engagement. Annals of Tourism Research, 175-192.

Chon K. (1999) Quality in Hospitality and Tourism Services. Australian Journal of Hospitality Management

Constantinides, E., \& Fountain, S. J. (2008). Web 2.0: conceptual Foundations and Marketing Issues. Journal of Direct Data and Digital Marketing Practice, 9(3), 231-244.

Dahlgren, P. (2013) Online Journalism and Civic Cosmopolitanism: Professional vs Participatory Ideals. Journalism Studies, 14 (2), 156-171

Daniel, M. (2016). Social Media in an English Village. London: UCL Press.

Davidson, R. (2011),"Web 2.0 as a marketing tool for conference centers, International Journal of Event and Festival Management. 2 (2), $117-138$

Del Giudice, M., Della Peruta, M. R., \& carayannis, E. G. (2014). Social Media and Emerging Economies Technological, Cultural and Economic Implications. New York: Springer.

DiStaso, M. W., \& McCorkindale, T. (2012). Social Media: Uses and Opportunity in Public Relations. Global Media Journal-- Canadain Edition, 5 (2), 75-82.

Edvardsson,B., Tronvoll,B. and Gruber,T.(2011) Expanding understanding of service exchange and value cocreation: a social construction approach. Journal of the academy of marketing science

Gensler, S., Volckner, F., Lui-Thompkins, Y., \& Wiertz, C. (2013). Managing Brands in the Social Media Environment. Journal of interactive Marking, 27, 242-256

Giudice, M. D., Peruta, M. R. D., Carayannis, E. G. (2014) Social Media and Emerging Economies: Technological, Cultural and Economic Implications. Retrieved from https://ebookcentral.proquest.com [24 May 2017]

Grueskin, B., Seave, A., Graves, L. (2011) Story So Far: What We Know about the Business of Digital Journalism. New York, USA: Columbia University Press

Gummesson, E. (2014). Productivity, Quality and Relationship Marketing in Service Operations: A Revisit in a New Service Paradigm. European Journal of Marketing, 26(5).

HAAS, T. (2005). From 'Public Journalism' to the 'Public's Journalism'? Rhetoric and Reality in the Discourse on Weblogs, 387-396. 
Harrigan,P and Miles,M.(2014) From e-CRM to s-CRM. Critical factors underpinning the social CRM activities of SMEs. Small Enterprise Research.21: 99-116

Harrison, J. (2010) User-Generated Content and Gatekeeping at the BBC Hub. Journalism Studies, 11 (2), 243 256

Harvey, K. (2014). Encyclopedia of Social Media and Politics. London: Sage Publications Ltd.

Hoegg, R., Martignoni, R., Meckel, M., \& StanoevskaSlabeva, K. (2006, September 28). Overview of business models for Web 2.0 communities. Retrieved from University of St. Gallen: https://www.alexandria.unisg.ch/31411/

Jonsson, A. M., \& Ornebring, H. (2011). User-generated Content and the News: Empowerment of Citizens or Interactive Illusion? Journalism Practice, 5(2), 127-144.

Kaul, A., Chaudhri, V., Cherian, D., Freberg, K., Mishra, S., Kumar, R., . . Carroll, C. E. (2015). Social Media: The New Mantra for Managing Reputation. The Journal for Decision Makers, 40(4), 455-491.

Kiralova, A., \& Antonin , P. (2015). Development Of Social Media Strategies in Toursim Destination. Social and Behavioral Sciences, 358-366.

Kozinets, V. R., De Valk, K., Wojnicki, A. C., \& Wilner, S. J. (2010). Networked Narratives: Understaning Word of Mouth Marketing in Online Communities. Journal of Marketing, 74(2), 71-89.

Labrecque, L., Esche ,V.J.,Mathwick ,C.,Novak ,P.T., and Hofacker ,F.C., (2013) Consumer power :Evolution in the digital age. Journal of interactive marketing. $27,257-269$

Leung, D., Law , R., Hoof, H. V., \& Buhalis, D. (2013). Social Media in Tourism and Hospitality: A Literature Review. Journal of Travel \& Tourism Marketing, 3-22.

Malthouse, C.E., Haenlein, M., Skeira, B., Wege,E. and Zhang,M. (2013) Managing customer relationship in the social media era:Introducing the social CRM house. Journal of interactive marketing. 27,270-280.

Miller, D., \& et al. (2016). How the World Changed Social Media. London: UCL Press.

Miller, D., Sinanan, J., Wang, X., McDonald, T., Haynes, N., Costa, E., . . . Nicolescu, R. (2016). How the World Changed Social Media. London: UCL Press.

Mok, C., Sparks , B., \& Kadampully, J. (2001). Service Quality Management in Hospitality, Tourism, and Leisure. New York: Routledge.

Omijeh, B. O., Chukueggu, C., \& Diugwu, C. (2020). Model for Maximising Broadband Penetration in Nigeria. Journal of Electronics and Communication Engineering, 25-31. Retrieved October 20, 2020, from www.iosrjournals.org

O'Reilly, T. (2005, 09 30). WHat is Web 2.0 Design Patterns and Bussiness Models for the Next Generation of Software. Retrieved from O'Reilly: http://www.oreilly.com/

Peter, K., Chen, Y., Kaplan, A. M., Ognibeni, B., \& Pauwels, K. (2013). Social Media Metric- A Framework and Guidelines for Managing Social Media . Journal of Interactive Marketing. 27, 281-298.

Ryan, D. (2015). Understanding Social Media: How to Create a Plan for Your Business that Works. London: Kogan Page.

Sashi ,C.M. (2012) Customer engagement, buyer-seller relationships, and social media. Management Decision. 50 (2), 253-272

Sule, G. M. (2016). Audience Participation in the Production of Digital News: a Content Analysis Of Channels Television (Nigeria).

Tom Bornhorst, J.R., Ritchie ,B. and Sheehan ,L. (2010)Determinants of tourism success for DMO's and destinations: An empirical examination of stakeholders perspectives. Tourism Management 31, 572-589.

Twente. (2017, Febraury 27). Diffusion of Innovation Theory. Retrieved from University of Twente: https://www.utwente.nl/en/bms/communication-theories/sorted-by-

cluster/Media\%2C\%20Culture\%20and\%20Society/gatekeeping/

Utwente.nl. (2017, February 27). Gatekeeoing. Retrieved from University of Twente: https://www.utwente.nl/en/bms/communication-theories/sorted-bycluster/Media\%2C\%20Culture\%20and\%20Society/gatekeeping/

Vargo, S. L. (2008). Customer Integration and Value Creation: Paradigmatic Traps and Perspectives. Journal of Service Research, 11(2), 211-215. 
Vargo, S. L., \& Lusch, R. F. (2004). Evolving to a New Dominant Logic for Marketing. Journal of Marketing, 68(1), 1-17.

Whitfield, J., \& Webber, D. J. (2010). Which Exhibition Attributes create Repeat Visitation? International Journal of Hospitality, 30(2), 439-447.

Wittel, L., Snyder, H., Gustafsson, A., Fombelled, P., \& Kristensson, P. (2016). Defining Service Innovation: A Review and Synthesis. Jounal of Business Research, 69(8), 2863-2872.

World Trade Organization. (2015). International Trade Statistics 2015. Geneva: World Trade Organization. Retrieved October 20/10/2020, 2020 